\title{
Dietary effects on muscle fatty acid composition of finished heifers ${ }^{(1)}$
}

\author{
Regiane Gregório da Silva(2), Ivanor Nunes do Prado(3), \\ Makoto Matsushita ${ }^{(4)}$ and Nilson Evelázio de Souza ${ }^{(4)}$
}

\begin{abstract}
The effects of diet on Longissimus muscle fatty acid composition was determined using 24 crossbred heifers of Simmental vs. Nelore and Limousin vs. Nelore. The experimental diets were: 1) corn and yeast (CY); 2) corn, cottonseed meal + meat and bones meal (CMB); 3) cassava hull and yeast $(\mathrm{CHY})$; 4 ) cassava hull, cottonseed meal + meat and bones meal (CHMB). Feeding CHMB diets resulted in lower lipid and higher cholesterol contents $(\mathrm{P}<0.05)$ for both crosses. Most of the identified fatty acids were monounsaturated, and the highest percentage was found to oleic acid (C18:1 $\omega 9)$, with values ranging from 32.54 to $46.42 \%$. Among the saturated fatty acids the palmitic acid (C16:0) showed the highest percentage, with its contents ranging between 19.40 and $32.44 \%$. The highest polyunsatu$\mathrm{rated} / \mathrm{saturated}$ fatty acid ratio was of 0.30 , and the lowest was of 0.08 . Feeding CY diets resulted in lower cholesterol and higher polyunsaturated fatty acid contents of the Longissimus muscle.
\end{abstract}

Index terms: muscles, rations, unsaturated fatty acids, saturated fatty acids.

\section{Efeitos de dietas sobre a composição em ácidos graxos de novilhas terminadas em confinamento}

Resumo - Efeitos de dietas sobre a composição em ácidos graxos no músculo Longissimus foram determinados, usando 24 novilhas mestiças Simmental vs. Nelore e Limousin vs. Nelore. As dietas experimentais foram: 1) milho e levedura (ML);2) milho, farelo de algodão + farinha de carne e ossos (MiACO); 3) casca de mandioca e levedura (ML); 4) casca de mandioca, farelo de algodão + farinha de carne e ossos (MaACO). Dietas com a ração MaACO resultaram em carne com baixo teor de lipídios e alto teor de colesterol $(\mathrm{P}<0,05)$ em ambas as raças. A maioria dos ácidos graxos identificados foram monoinsaturados, com maior porcentagem para o ácido oléico (C18:1 $\omega 9)$, com valores variando de 32,54 a 46,42\%. Entre os ácidos graxos saturados, o palmítico (C16:0) mostrou a maior porcentagem, variando de 19,40 a $32,44 \%$. A maior razão ácido graxo poliinsaturado/saturado foi de 0,30 (ML) e a menor de 0,08 (MiACO). A carne de novilhas alimentadas com a dieta ML apresentou menor teor de colesterol e maior teor de ácidos graxos poliinsaturados.

Termos para indexação: músculos, ração, ácidos graxos insaturados, ácidos graxos saturados.

\section{Introduction}

Efforts to improve the cattle productivity through breeding or nutritional changes may only be completed when the composition and palatability of the meat are considered (Mills et al., 1992). Beef con-

\footnotetext{
(1) Accepted for publication on December 19, 2000. Extracted from M.Sc. Dissertation presented by the first author to Universidade Estadual de Maringá (UEM), Maringá, PR.

${ }^{(2)}$ Capes fellow. E-mail: regianegs@hotmail.com.br

(3)UEM, Dep. de Zootecnia, CEP 87020-900 Maringá, PR. E-mail: inprado@uem.br

(4)UEM, Dep. de Química. E-mail: mmakoto@uem.br, nesouza@uem.br
}

sumption provides high quality proteins and essential vitamins and minerals; however its saturated fatty acids and cholesterol contents have led to a negative image of beef by some consumers (Rule et al., 1997). Even so, beef possesses similar or smaller cholesterol levels when compared to other meat sources (Feeley et al., 1972), and the harmful effect on the total cholesterol and LDL levels is related to the lipid fraction of the meat and not to the lean meat (O'Dea et al., 1990). Red meat, however, has the worst reputation in terms of a healthy human diet (Aharoni et al., 1995). Beef fat is a significant saturated fatty acid source in a diet. The diverse effect of saturated fatty acids in the plasma cholesterol makes 
it important to include fatty acid analysis in the evaluation of the meat composition (Mills et al., 1992).

Feedlot is one of the systems used to increase the breeding productivity of beef cattle, with positive effects on the carcass quality and on the meat offered between the harvest seasons. However, the success of the intensive exploration of beef cattle in feedlot is related to the available supply and cost of the used rations.

The purpose of this study was to determine the effect of diet on Longissimus muscle composition and fatty acid profiles of crossbred heifers finished in a feedlot.

\section{Material and Methods}

Animals were finished in the beef cattle Section of Iguatemi Experimental Farm, which belongs to the Universidade Estadual de Maringá, PR, Brazil. Twentyfour crossbred heifers were used with equal numbers of Limousin-Nelore and Simmental-Nelore crosses. These groups were distributed into four treatments: 1) corn $(33.65 \%)$ and yeast $(16.35 \%)(\mathrm{CY}) ; 2)$ corn $(24.04 \%)$, cottonseed meal $(20.91 \%)$ meat and bones meal $(5.00 \%)$ (CMB); 3) cassava hull $(31.85 \%)$ and yeast $(18.15 \%)$ (CHY); 4) cassava hull $(22.12 \%)$, cottonseed meal $(22.84 \%)+$ meat and bones meal $(5.00 \%)$ (CHMB). All the diets contained corn silage $(50.00 \%)$, phosphate and mineral salts. At the age of 15 months they were fed at a common feedlot. Slaughtering started after 80 days of drylot. At the starting point, heifers showed a mean liveweight of $303 \mathrm{~kg}$ and were approximately 18 months of age. Diets were composed of two energy sources (corn or cassava hull) and two protein sources (yeast or cottonseed meal).

After the establishment of the rigor mortis state, a 20-cm-thick section of the Longissimus dorsi muscle (LD), corresponding to the 11 th to the 12 th rib section, was taken from the left side of each carcass. All samples were stored in freezer $\left(-18^{\circ} \mathrm{C}\right)$, after removal of all external fat. Chemical analysis were carried out in triplicate using homogenized thawed muscle samples.

For the moisture, ash and protein contents were determined as described by Cunniff (1998). Lipids were extracted from the muscle tissues using the modified Folch et al. (1957) method. Meat samples $(15.00 \pm 0.01 \mathrm{~g})$ were homogenized with $90 \mathrm{~mL}$ of chloroform-methanol $(2: 1 \mathrm{v} / \mathrm{v})$ solution for two minutes, using a blender, followed by the addition of $30 \mathrm{~mL}$ of chloroform and $30 \mathrm{~mL}$ of deionized water. This mixture was once more blended for other two minutes. Then, a $0.58 \%$ aqueous $\mathrm{NaCl}$ solution was added to the mixture, causing the chloroform layer (containing lipid) to separate from the methanol-water phase. The lipid extract solution was transferred to a $250 \mathrm{~mL}$ flask and the solvent evaporated under a nitrogen flux. The lipid content was gravimetrically determined.

The extraction and quantification of the cholesterol were carried out by the method of Al-Hasani et al. (1993), with modifications. Samples of the LD muscle (5-10 g) were placed in a $250 \mathrm{~mL}$ flat-bottom flask. The sample was dispersed in an ethanol-methanol-isopropanol (90:5:5 v/v/v) solution in an amount equivalent to $6 \mathrm{~mL} / \mathrm{g}$ sample and $60 \% \mathrm{KOH}$ in an amount of $1 \mathrm{~mL}$ per gram of sample. The flask containing the mixture was connected to a water-cooled condenser, and refluxed for one hour. After cooling the digest to room temperature, $100 \mathrm{~mL}$ of hexane was added, and the mixture stirred for 10 minutes. Next $25 \mathrm{~mL}$ of deionized water were added and the mixture stirred for another 15 minutes. The layers were then separated and the hexane layer was collected in a flask. An aliquot of $25 \mathrm{~mL}$ from the hexane layer was evaporated to dryness under a stream of nitrogen. The residue was dissolved in $2 \mathrm{~mL}$ of hexane containing $0.2 \mathrm{mg}$ of $5 \alpha$-cholestane internal standard per $\mu \mathrm{L}$ and transferred to a sample vial. Cholesterol analysis were done using $3 \mu \mathrm{L}$ of this solution injected into a gas chromatograph (Shimadzu 14 A, Japan) fitted with flame ionization detector $\left(\mathrm{FID}, 300^{\circ} \mathrm{C}\right)$ and a split/splitless injector $\left(260^{\circ} \mathrm{C}\right.$, split $1: 150)$. Separation was carried out $\left(300^{\circ} \mathrm{C}\right)$ in a fused silica capillary column ( $25 \mathrm{~m}, 0.25 \mathrm{~mm}$ i.d.), coated with SE-30 (0.25 $\mu \mathrm{m}$ phase thickness). The carrier gas was hydrogen $(1.5 \mathrm{~mL} / \mathrm{min})$ and the makeup gas was nitrogen ( $25 \mathrm{~mL} / \mathrm{min})$. Cholesterol identifications were made by comparing the relative retention time peaks from samples with standards from Sigma (USA). For peak integration a CG-300 Computing integrator program (CG Instruments, Brazil) was used.

Methyl esters were prepared by transmethylation according to the procedure of the International Organization for Standardization (1978), using KOH $2 \mathrm{~mol} / \mathrm{L}$ in methanol and $n$-heptane. Fatty acid methyl esters (FAME) were analyzed using a Shimadzu 14A (Japan) gas chromatograph equipped with flame ionization detector and Fused Silica capillary column $(50 \mathrm{~m} \times 0.25 \mathrm{~mm}$ and $0.20 \mu \mathrm{m}$ of Carbowax 20M). The column temperature was programmed at $10^{\circ} \mathrm{C} / \mathrm{min}$ from $150-240^{\circ} \mathrm{C}$. The injection port and detector were maintained at $220^{\circ} \mathrm{C}$ and $245^{\circ} \mathrm{C}$, respectively. The carrier gas was hydrogen $(1.2 \mathrm{~mL} / \mathrm{min})$ 
and the makeup gas was nitrogen $(30 \mathrm{~mL} / \mathrm{min})$. The split used was $1 / 100$. The identification of fatty acids was made by comparing the relative retention times of FAME peaks from samples with standards from Sigma (USA). The separation of FAME was carried out in a fused silica capillary column ( $50 \mathrm{~m}, 0.25 \mathrm{~mm}$ i.d.) coated with Carbowax $20 \mathrm{M}$ (film thickness $0.20 \mu \mathrm{m}$ ) using the following program: $150-240^{\circ} \mathrm{C}, 10^{\circ} \mathrm{C} / \mathrm{min}$. Helium was used as carrier gas $(0.7 \mathrm{~mL} / \mathrm{min})$. The peak areas were determined by the CG-300 computing integrator program (CG Instruments, Brazil). Data were calculated as normalized area percentages of fatty acids.

The experimental data are shown as mean \pm standard deviations were statistically compared by Tukey test at 5\% with one-way ANOVA as described by Montgomery (1997). Data were processed in the Statistica 5.1 Software (Statistica, 1996).

\section{Results and Discussion}

The chemical composition and the fatty acid profiles of the experimental diets are presented in Tables 1 and 2, respectively. The CY diet presented higher fat levels than the other diets. However, the CY diet presented the highest quantities of unsaturated fatty acids (Table 2).

No difference in water contents was observed between diets $(\mathrm{P}>0.05)$, which ranged from 74.47 to $74.83 \%$ (Table 3 ). However, ash, protein, fat and cholesterol contents presented significant differences $(\mathrm{P}<0.05)$ between diets with values ranging

Table 1. Chemical composition (\%) of experimental $\operatorname{diets}^{(1)}$.

\begin{tabular}{lrrrr}
\hline Chemical composition & CY & CMB & CHY & CHMB \\
\hline Fat & 2.89 & 2.00 & 1.42 & 1.23 \\
DM & 47.27 & 47.85 & 47.30 & 47.63 \\
CP & 12.69 & 13.36 & 10.88 & 12.38 \\
OM & 96.79 & 94.72 & 95.76 & 94.12 \\
ME\# & 1.97 & 1.70 & 2.37 & 2.17 \\
Ash & 3.03 & 5.00 & 3.93 & 5.65 \\
NDF & 36.17 & 45.70 & 41.22 & 50.11 \\
ADF & 19.66 & 26.67 & 24.75 & 30.90 \\
Starch & 35.79 & 26.70 & 30.30 & 22.17 \\
Calcium & 0.39 & 0.72 & 0.52 & 0.81 \\
Phosphorus & 0.41 & 0.64 & 0.33 & 0.59 \\
\hline
\end{tabular}

(1)Data of the Animal Food, Laboratório de Análises de Rações e Nutrição, Departamento de Zootecnia, Universidade Estadual de Maringá; CY: corn and yeast diet; CMB: corn, cottonseed meal + meat and bones flour diet; CHY: cassava hull and yeast diet; CHMB: cassava hull, cottonseed meal + meat and bones flour diet; DM: dry matter; $\mathrm{CP}$ : crude protein; OM: organic matter; ME\#: megacalories, gross energy; NDF: neutral detergent fiber; ADF: acid detergent fiber. from 0.95 to $1.05 \%, 22.54$ to $23.90 \%, 0.75$ to $1.95 \%$ and 37.37 to $49.07 \mathrm{mg} / 100 \mathrm{~g}$, respectively. For the crossbreeds of the Simmental and Nelore breeds there were no significant differences $(\mathrm{P}>0.05)$ in relation to the moisture $(74.35 \%$ to $75.16 \%)$ and protein $(22.07 \%$ to $22.77 \%$ ) contents. Ash, fat and cholesterol presented significant differences $(\mathrm{P}>0.05)$ with contents ranging from 0.94 to $1.05 \%, 1.10$ to $2.13 \%$ and 18.46 to $51.75 \mathrm{mg} / 100 \mathrm{~g}$, respectively.

The values found for the protein content were similar to the ones found by Koevering et al. (1995), which varied from 22.12 to $22.70 \%$ for heifers, $22.2 \%$ for ostrich meat and were higher than the ones found for turkey (20.4\%) (Paleari et al., 1998) and lamb meat, varying from 19.28 to $19.39 \%$ for feedlot and pasture (Rowe et al., 1999). A low fat value was observed by Abularach et al. (1998) in his studies with young bulls of the Nelore breed (1.71\%). These values are close to the ones of the ostrich meat (1.60\%).

Table 2. Fatty acids profile of $\operatorname{diets}^{(1)}$.

\begin{tabular}{|c|c|c|c|c|}
\hline Fatty acids & CY & CMB & CHY & CHMB \\
\hline $\mathrm{C} 12: 0$ & nd & nd & $0.28 \pm 0.03$ & $0.34 \pm 0.00$ \\
\hline C14:0 & nd & $0.36 \pm 0.03$ & $0.52 \pm 0.00$ & $1.55 \pm 0.09$ \\
\hline $\mathrm{C} 14: 1 \omega 5$ & nd & nd & $0.30 \pm 0.02$ & nd \\
\hline C15:0 & nd & $0.12 \pm 0.01$ & $0.37 \pm 0.04$ & $0.74 \pm 0.23$ \\
\hline C16:0 & $12.17 \pm 0.30$ & $14.69 \pm 0.43$ & $25.39 \pm 1.13$ & $28.62 \pm 0.69$ \\
\hline$C 16: 1 \omega 7$ & $0.16 \pm 0.01$ & $0.16 \pm 0.01$ & $0.34 \pm 0.02$ & $0.28 \pm 0.04$ \\
\hline C17:0 & $0.10 \pm 0.01$ & $0.40 \pm 0.02$ & $1.14 \pm 0.01$ & $1.99 \pm 0.00$ \\
\hline $\mathrm{C} 17: 1 \omega 10$ & nd & $0.07 \pm 0.01$ & nd & $0.20 \pm 0.02$ \\
\hline C18:0 & $2.45 \pm 0.04$ & $7.67 \pm 0.23$ & $7.86 \pm 0.51$ & $30.82 \pm 0.83$ \\
\hline C18:1 19 & $32.25 \pm 0.75$ & $28.61 \pm 0.83$ & $17.04 \pm 0.76$ & $12.48 \pm 0.51$ \\
\hline $\mathrm{C} 18: 2 \omega 6$ & $49.42 \pm 0.80$ & $43.98 \pm 0.82$ & $30.60 \pm 0.86$ & $13.71 \pm 0.21$ \\
\hline 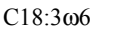 & $0.13 \pm 0.01$ & $0.10 \pm 0.02$ & $1.99 \pm 0.23$ & $0.84 \pm 0.09$ \\
\hline $\mathrm{C} 18: 3 \omega 3$ & $0.98 \pm 0.03$ & $0.81 \pm 0.04$ & $3.92 \pm 0.17$ & $4.35 \pm 0.58$ \\
\hline C20:0 & $0.62 \pm 0.01$ & $0.57 \pm 0.01$ & $2.29 \pm 0.05$ & $0.71 \pm 0.02$ \\
\hline $\mathrm{C} 20: 1 \omega 9$ & $0.45 \pm 0.04$ & $0.39 \pm 0.03$ & $1.18 \pm 0.04$ & $0.62 \pm 0.11$ \\
\hline $\mathrm{C} 20: 5 \omega 3$ & $0.30 \pm 0.04$ & $0.56 \pm 0.01$ & $1.47 \pm 0.01$ & nd \\
\hline $\mathrm{C} 22: 0$ & $0.26 \pm 0.04$ & $0.42 \pm 0.05$ & nd & $1.43 \pm 0.08$ \\
\hline $\mathrm{C} 22: 1 \omega 3$ & $0.33 \pm 0.00$ & $0.47 \pm 0.03$ & nd & nd \\
\hline $\mathrm{C} 22: 2 \omega 6$ & nd & nd & $2.02 \pm 0.23$ & nd \\
\hline C23:0 & nd & nd & $1.28 \pm 0.07$ & $0.69 \pm 0.19$ \\
\hline $\mathrm{C} 24: 0$ & $0.32 \pm 0.01$ & $0.52 \pm 0.03$ & $1.83 \pm 0.23$ & $0.62 \pm 0.09$ \\
\hline SFA & $15.92 \pm 0.30$ & $24.75 \pm 0.49$ & $41.68 \pm 1.28$ & $66.48 \pm 1.41$ \\
\hline MUFA & $32.74 \pm 0.75$ & $29.31 \pm 0.84$ & $18.85 \pm 0.78$ & $14.27 \pm 0.56$ \\
\hline PUFA & $51.28 \pm 0.80$ & $45.84 \pm 0.83$ & $37.98 \pm 0.91$ & $18.91 \pm 0.62$ \\
\hline$\omega 6$ & $49.55 \pm 0.80$ & $44.08 \pm 0.82$ & $34.61 \pm 0.92$ & $14.55 \pm 0.23$ \\
\hline$\omega 3$ & $1.60 \pm 0.05$ & $1.84 \pm 0.05$ & $5.39 \pm 0.17$ & $4.35 \pm 0.58$ \\
\hline $\mathrm{P} / \mathrm{S}$ & $3.22 \pm 0.08$ & $1.85 \pm 0.05$ & $0.91 \pm 0.03$ & $0.28 \pm 0.01$ \\
\hline$\omega 6 / \omega 3$ & $30.78 \pm 1.08$ & $23.96 \pm 0.80$ & $6.05 \pm 0.25$ & $2.88 \pm 0.39$ \\
\hline
\end{tabular}

(1)Each value is an average of three samples, with its standard deviations; CY: corn and yeast diet; CMB: corn, cottonseed meal + meat and bones flour diet; $\mathrm{CHY}$ : cassava hull and yeast diet; CHMB: cassava hull, cottonseed meal + meat and bones flour diet; nd: not detected; SFA, MUFA and PUFA: saturated, monounsaturated and polyunsaturated fatty acids; $\mathrm{P} / \mathrm{S}$ : ratio of polyunsaturated to saturated fatty acids; $\omega 6 / \omega 3$ : ratio of $\omega 6$ to $\omega 3$ fatty acids. 
Table 3. Diet effects on the Longissimus dorsi muscle composition of Limousin vs. Nelore and Simmental vs. Nelore heifer crosses $^{(1)}$.

\begin{tabular}{|c|c|c|c|c|c|c|c|c|}
\hline \multirow[t]{2}{*}{ Diets } & \multicolumn{4}{|c|}{ Limousin vs. Nelore } & \multicolumn{4}{|c|}{ Simmental vs. Nelore } \\
\hline & $\mathrm{CY}$ & CMB & $\mathrm{CHY}$ & CHMB & $\mathrm{CY}$ & CMB & $\mathrm{CHY}$ & CHMB \\
\hline Ash $(\%)$ & $0.97 \mathrm{a} \pm 0.03$ & $1.01 \mathrm{ab} \pm 0.03$ & $0.95 \mathrm{ac} \pm 0.04$ & $0.99 a \pm 0.02$ & $1.01 \mathrm{a} \pm 0.03$ & $0.94 \mathrm{~b} \pm 0.02$ & $1.05 \mathrm{c} \pm 0.02$ & $1.02 \mathrm{a} \pm 0.03$ \\
\hline Fat $(\%)$ & $1.95 \mathrm{a} \pm 0.14$ & $1.73 a \pm 0.13$ & $1.08 \mathrm{~b} \pm 0.02$ & $0.75 c \pm 0.05$ & $1.46 \mathrm{a} \pm 0.15$ & $1.94 b \pm 0.12$ & $2.13 \mathrm{~b} \pm 0.11$ & $1.10 \mathrm{a} \pm 0.13$ \\
\hline Cholesterol (mg/100 g & $40.04 a \pm 1.31$ & $42.93 \mathrm{ab} \pm 2.57$ & $37.37 \mathrm{a} \pm 0.71$ & $49.07 \mathrm{~b} \pm 3.53$ & $18.46 \mathrm{a} \pm 2.37$ & $51.75 \mathrm{~b} \pm 2.34$ & $25.42 \mathrm{a} \pm 2.94$ & $43.87 \mathrm{~b} \pm 4.07$ \\
\hline
\end{tabular}

${ }^{(1)}$ Each value is an average of three samples in triplicates, with its standard deviations; the means followed by same letters are note different by Tukey test at 5\%; CY: corn and yeast diet; CMB: corn, cottonseed meal + meat and bones flour diet; CHY: cassava hull and yeast diet; CHMB: cassava hull, cottonseed meal + meat and bones flour diet.

Cholesterol contents were higher for heifers fed with the CHMB and CMB rations, probably due to the presence of the meat and bones meal, added to the cottonseed meal. These values are similar to the ones found by Koevering et al. (1995), which were of $49.35 \mathrm{mg} / 100 \mathrm{~g}$ for beef, and to the ones found by Paleari et al. (1998), which were of $36.60 \mathrm{mg} / 100 \mathrm{~g}$ for turkey meat and of $33.80 \mathrm{mg} / 100 \mathrm{~g}$ for ostrich meat.

These are smaller values than the ones found by Bohac \& Rhee (1988) for beef and pork, which were of $56.00 \mathrm{mg} / 100 \mathrm{~g}$ and $55.9 \mathrm{mg} / 100 \mathrm{~g}$, respectively, and smaller than the ones found by Rowe et al. (1999), for lambs fattened in feedlot and pasture, which were of 57.76 and $62.03 \mathrm{mg} / 100 \mathrm{~g}$, respectively and smaller than the ones found by Holland et al. (1993), in a study with chickens and beef, that determined 57.00 and $59.00 \mathrm{mg} / 100 \mathrm{~g}$ of cholesterol, respectively.

Most of the identified fatty acids were

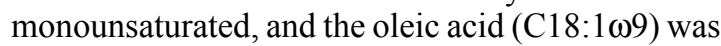
the one present in higher percentage, with values between 32.54\%, for Simmental and Nelore (CHMB) and $46.42 \%$, for Limousin and Nelore (CMB) breeds (Tables 4 and 5). After these ones, the acids which were identified in a larger amount were the saturated fatty acids, and the palmitic acid (C16:0) was the one found in the largest amount, with its content between $19.40 \%$ for Simmental and Nelore (CMB) and $26.35 \%$ for Limousin and Nelore (CMB). The stearic acid (C18:0) was found in a considerable amount and

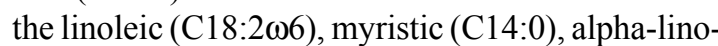
lenic $(\mathrm{C} 18: 3 \omega 3)$ acids were also found in all the samples. It is important to point out that under metabolic conditions, replacement of carbohydrates by lauric, miristic and palmitic acids raised both the low
Table 4. Diet effects on the fatty acid profile Longissimus dorsi muscle of the Limousin and Nelore crosses ${ }^{(1)}$.

\begin{tabular}{|c|c|c|c|c|}
\hline Fatty acids & $\mathrm{CY}$ & CMB & CHY & CHMB \\
\hline C14:0 & $2.52 \mathrm{a} \pm 0.27$ & $3.26 \mathrm{ab} \pm 0.20$ & $2.09 \mathrm{ac} \pm 0.22$ & $2.60 \mathrm{a} \pm 0.06$ \\
\hline 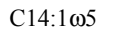 & $0.67 \mathrm{a} \pm 0.01$ & $0.51 \mathrm{ab} \pm 0.03$ & $0.43 b \pm 0.03$ & nd \\
\hline C15:0 & $0.26 \mathrm{a} \pm 0.02$ & $0.44 \mathrm{a} \pm 0.01$ & $0.32 \mathrm{a} \pm 0.05$ & nd \\
\hline C16:0 & $24.02 \mathrm{a} \pm 2.22$ & $25.44 \mathrm{a} \pm 1.52$ & $21.91 \mathrm{a} \pm 0.49$ & $26.35 \mathrm{a} \pm 1.84$ \\
\hline $\mathrm{C} 16: 1 \omega 7$ & $4.60 \mathrm{a} \pm 0.32$ & $3.88 \mathrm{ab} \pm 0.30$ & $3.68 \mathrm{~b} \pm 0.21$ & $3.21 \mathrm{~b} \pm 0.36$ \\
\hline $\mathrm{C} 17: 0$ & $0.74 \mathrm{a} \pm 0.08$ & $0.95 \mathrm{ab} \pm 0.09$ & $1.43 b \pm 0.20$ & $0.91 \mathrm{ab} \pm 0.08$ \\
\hline $\mathrm{C} 17: 1 \omega 7$ & $0.97 \mathrm{a} \pm 0.11$ & $0.82 \mathrm{a} \pm 0.06$ & $1.94 \mathrm{ab} \pm 0.34$ & $0.73 \mathrm{ac} \pm 0.13$ \\
\hline C18:0 & $11.74 \mathrm{a} \pm 0.97$ & $14.55 \mathrm{ab} \pm 1.01$ & $15.69 \mathrm{~b} \pm 0.82$ & $17.20 \mathrm{~b} \pm 1.78$ \\
\hline $\mathrm{C} 18: 1 \omega 9$ & $43.01 \mathrm{a} \pm 5.21$ & $46.42 \mathrm{a} \pm 4.42$ & $39.20 \mathrm{a} \pm 1.03$ & $43.18 \mathrm{a} \pm 3.74$ \\
\hline $\mathrm{C} 18: 2 \omega 6$ & $3.08 \mathrm{a} \pm 0.23$ & $1.94 \mathrm{~b} \pm 0.11$ & $3.21 \mathrm{a} \pm 0.13$ & $2.82 \mathrm{ab} \pm 0.10$ \\
\hline $\mathrm{C} 18: 3 \omega 6$ & $0.89 \mathrm{a} \pm 0.15$ & $0.36 \mathrm{a} \pm 0.02$ & $2.57 \mathrm{~b} \pm 0.25$ & $0.58 \mathrm{a} \pm 0.07$ \\
\hline $\mathrm{C} 18: 3 \omega 3$ & $3.08 \mathrm{a} \pm 0.98$ & $0.60 \mathrm{~b} \pm 0.04$ & $2.00 \mathrm{a} \pm 0.11$ & $0.71 b \pm 0.06$ \\
\hline $\mathrm{C} 20: 3 \omega 3$ & $0.45 \mathrm{a} \pm 0.04$ & nd & $1.84 \mathrm{~b} \pm 0.10$ & nd \\
\hline $\mathrm{C} 20: 4 \omega 6$ & $2.36 \mathrm{a} \pm 0.33$ & $0.83 b \pm 0.08$ & $2.29 \mathrm{a} \pm 0.14$ & $0.89 \mathrm{~b} \pm 0.01$ \\
\hline C24:0 & $0.69 a \pm 0.08$ & nd & $1.19 b \pm 0.06$ & nd \\
\hline Others & $0.94 \mathrm{a} \pm 0.12$ & $0.82 \mathrm{a} \pm 0.09$ & $0.22 \mathrm{~b} \pm 0.04$ & $0.83 a \pm 0.09$ \\
\hline SFA & $39.97 \mathrm{a} \pm 2.44$ & $44.64 \mathrm{ab} \pm 1.84$ & $42.62 \mathrm{ab} \pm 1.01$ & $47.06 \mathrm{~b} \pm 2.56$ \\
\hline MUFA & $49.25 \mathrm{a} \pm 5.22$ & $50.81 \mathrm{a} \pm 4.43$ & $45.25 \mathrm{a} \pm 1.10$ & $47.12 \mathrm{a} \pm 3.76$ \\
\hline PUFA & $9.85 \mathrm{a} \pm 1.12$ & $3.73 b \pm 0.14$ & $11.91 \mathrm{c} \pm 0.35$ & $5.00 \mathrm{~d} \pm 0.14$ \\
\hline$\omega 6$ & $6.33 \mathrm{a} \pm 0.43$ & $3.13 b \pm 0.14$ & $8.07 \mathrm{c} \pm 0.32$ & $4.29 \mathrm{~d} \pm 0.12$ \\
\hline$\omega 3$ & $3.53 \mathrm{a} \pm 0.98$ & $0.60 \mathrm{~b} \pm 0.04$ & $3.84 \mathrm{a} \pm 0.14$ & $0.71 \mathrm{~b} \pm 0.06$ \\
\hline $\mathrm{P} / \mathrm{S}$ & $0.25 \mathrm{a} \pm 0.03$ & $0.08 b \pm 0.01$ & $0.28 \mathrm{a} \pm 0.01$ & $0.11 \mathrm{~b} \pm 0.01$ \\
\hline$\omega 6 / \omega 3$ & $1.79 \mathrm{a} \pm 0.51$ & $5.22 \mathrm{~b} \pm 0.47$ & $2.10 \mathrm{c} \pm 0.11$ & $6.04 \mathrm{~d} \pm 0.54$ \\
\hline
\end{tabular}

(1)Each value is an average of three samples, with its standard deviations; the means followed by same letters are not different by Tukey test at $5 \%$; $\mathrm{CY}$ : corn and yeast diet; CMB: corn, cottonseed meal + meat and bones flour diet; $\mathrm{CHY}$ : cassava hull and yeast diet; CHMB: cassava hull, cottonseed meal + meat and bones flour diet; nd: not detected; SFA, MUFA, PUFA, $\omega 6$ and $\omega 3$ : saturated, monounsaturated, polyunsaturated, omega- 6 and omega-3 fatty acids; $\mathrm{P} / \mathrm{S}$ : ratio of polyunsaturated to saturated fatty acids; $\omega 6 / \omega 3$ : ratio of $\omega 6$ to $\omega 3$ fatty acids.

density lipoproteins (LDL) and the high density lipoprotein (HDL)-cholesterol, whereas the stearic acid had a small effect. The oleic and linoleic acids raised the HDL and slightly lowered the LDL (Katan et al., 1994).

Enser et al. (1996) compared the fatty acid composition of the muscle in beef, lambs and pork, and noted differences not only between ruminants and non-ruminants but also between beef and lamb. Beef presented smaller levels of the $\mathrm{C} 18: 2 \omega 6$ and $\mathrm{C} 18: 3 \omega 3$ 
fatty acids, but larger levels of the C16:0, C16:1cis, $\mathrm{C} 18: 1 \omega 9$ and $\mathrm{C} 20: 4 \omega 3$ fatty acids, in relation to other kinds of meat, and had intermediate values of the C18:0 acid, this value was close to the value found for pork and lower than the lamb value. It was observed that the $\omega 6 / \omega 3$ ratio is smaller in ruminant meat (beef, 2.1 and lamb, 1.3) than in non-ruminant (pork, 7.2).

Paleari et al. (1998) made comparisons between the muscular composition of beef, ostrich and turkey, and verified that beef presents higher levels of the $\mathrm{C} 18: 0, \mathrm{C} 18: 1 \omega 9$ and $\mathrm{C} 18: 2 \omega 6$ fatty acids, and smaller levels of the $C 16: 0, C 18: 3 \omega 3$ and $C 20: 4 \omega 3$ fatty acids than the ostrich and turkey meat.

Analyzing the fatty acids due to their saturation, meat samples of Limousin and Nelore heifers, fed with CMB ration have larger MUFA amount (50.81\%), but smaller $\mathrm{P} / \mathrm{S}$ (total) ratio (0.08). Simmental and Nelore animals fed with CY presented a higher PUFA/ SFA ratio, of 0.30 , a value slightly smaller than the value of 0.45 recommended by the Department of Health (England, 1994). A decrease in this value indicates foods that are not very healthy, in relation to cardiovascular diseases. This can reflect the composition of the diet, which possesses a large fat content and therefore high levels of polyunsaturated fatty acids.

Highly concentrated diets that reduce the ruminal $\mathrm{pH}$ could limit the extent of biohydrogenation in the rumen, ultimately allowing the passage for more unsaturated fatty acids to the small intestine for absorption and incorporation into tissues (Eichorn et al., 1986).

When comparing the $\omega 6 / \omega 3$ ratio to the recommended value of 4.0 (smaller values are more beneficial) (England, 1994), it is observed that the CY (1.79 for Limousin and Nelore and 2.00 for Simmental and Nelore), CHY (2.10 for Limousin and Nelore and 1.04 for Simmental and Nelore) diets have a beneficial aspect from the nutritional point of view on the beef muscle.

The meat fatty acid content, which is increasingly important to consumers, was influenced by the diet. The magnitude of the fatty acid content observed in this study was of great nutritional significance to people who eat meat.

Table 5. Diet effects on the fatty acid profile Longissimus dorsi muscle of the Simmental and Nelore crosses ${ }^{(1)}$.

\begin{tabular}{|c|c|c|c|c|}
\hline Fatty acids & $\mathrm{CY}$ & $\mathrm{CMB}$ & $\mathrm{CHY}$ & CHMB \\
\hline C14:0 & $1.76 \mathrm{a} \pm 0.03$ & $2.10 \mathrm{ab} \pm 0.31$ & $2.49 \mathrm{~b} \pm 0.44$ & $3.36 \mathrm{~b} \pm 0.06$ \\
\hline $\mathrm{C} 14: 1 \omega 5$ & $0.37 \mathrm{a} \pm 0.05$ & $0.45 \mathrm{a} \pm 0.07$ & $0.32 \mathrm{a} \pm 0.01$ & $2.26 \mathrm{~b} \pm 0.34$ \\
\hline $\mathrm{C} 15: 0$ & $0.66 \mathrm{a} \pm 0.11$ & $0.42 \mathrm{a} \pm 0.14$ & $0.32 \mathrm{a} \pm 0.03$ & $4.42 b \pm 0.42$ \\
\hline C16:0 & $21.86 \mathrm{abc} \pm 1.63$ & $23.34 \mathrm{ab} \pm 1.76$ & $25.33 \mathrm{~b} \pm 1.94$ & $19.40 \mathrm{c} \pm 0.29$ \\
\hline $\mathrm{C} 16: 1 \omega 7$ & $3.13 \mathrm{a} \pm 0.38$ & $3.51 \mathrm{ab} \pm 0.17$ & $2.62 \mathrm{a} \pm 0.09$ & $4.37 b \pm 0.62$ \\
\hline C17:0 & $0.74 a \pm 0.13$ & $0.80 \mathrm{a} \pm 0.03$ & $1.02 \mathrm{a} \pm 0.16$ & $2.80 \mathrm{~b} \pm 0.20$ \\
\hline 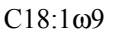 & $43.69 \mathrm{a} \pm 4.99$ & $41.68 \mathrm{a} \pm 1.95$ & $42.31 \mathrm{a} \pm 2.29$ & $32.54 b \pm 2.84$ \\
\hline $\mathrm{C} 18: 2 \omega 6$ & $5.65 \mathrm{abc} \pm 0.59$ & $7.63 b \pm 0.21$ & $1.47 \mathrm{c} \pm 0.16$ & $4.60 \mathrm{~d} \pm 0.61$ \\
\hline $\mathrm{C} 18: 3 \omega 6$ & $2.02 b \pm 0.12$ & $0.73 a \pm 0.16$ & $2.27 \mathrm{~b} \pm 0.13$ & nd \\
\hline $\mathrm{C} 18: 3 \omega 3$ & $3.16 \mathrm{a} \pm 0.34$ & $1.05 \mathrm{~b} \pm 0.08$ & $2.94 \mathrm{a} \pm 0.11$ & $2.61 \mathrm{a} \pm 0.37$ \\
\hline $\mathrm{C} 20: 3 \omega 3$ & $0.68 \mathrm{a} \pm 0.16$ & $0.39 \mathrm{a} \pm 0.08$ & $0.65 a \pm 0.30$ & nd \\
\hline SFA & $38.31 \mathrm{a} \pm 1.81$ & $42.55 \mathrm{ac} \pm 2.30$ & $46.52 b c \pm 2.32$ & $49.68 \mathrm{~b} \pm 2.12$ \\
\hline MUFA & $49.00 \mathrm{a} \pm 5.01$ & $46.30 \mathrm{a} \pm 1.96$ & $45.91 \mathrm{a} \pm 2.29$ & $42.80 \mathrm{a} \pm 2.93$ \\
\hline PUFA & $11.50 \mathrm{a} \pm 0.69$ & $10.53 \mathrm{a} \pm 0.36$ & $7.32 \mathrm{~b} \pm 0.41$ & $7.21 \mathrm{~b} \pm 0.71$ \\
\hline$\omega 6$ & $7.67 \mathrm{a} \pm 0.60$ & $9.09 b \pm 0.34$ & $3.74 c \pm 0.21$ & $9.60 b \pm 0.61$ \\
\hline$\omega 3$ & $3.84 \mathrm{a} \pm 0.38$ & $1.44 b \pm 0.11$ & $3.59 \mathrm{a} \pm 0.30$ & $2.61 c \pm 0.37$ \\
\hline $\mathrm{P} / \mathrm{S}$ & $0.30 \mathrm{a} \pm 0.03$ & $0.25 \mathrm{a} \pm 0.02$ & $0.16 b \pm 0.11$ & $0.15 b \pm 0.02$ \\
\hline$\omega 6 / \omega 3$ & $2.00 \mathrm{a} \pm 0.03$ & $6.31 \mathrm{~b} \pm 0.55$ & $1.04 \mathrm{c} \pm 0.10$ & $1.76 \mathrm{~d} \pm 0.27$ \\
\hline
\end{tabular}

${ }^{(1)}$ Each value is an average of three samples, with its standard deviations; the means followed by same letters are not different by Tukey test at $5 \%$; CY: corn and yeast diet; CMB: corn, cottonseed meal + meat and bones flour diet; CHY: cassava hull and yeast diet; CHMB: cassava hull, cottonseed meal + meat and bones flour diet; nd: not detected; SFA, MUFA, PUFA, $\omega 6$ and $\omega 3$ : saturated, monounsaturated, polyunsaturated, omega- 6 and omega- 3 fatty acids; P/S: ratio of polyunsaturated to saturated fatty acids; $\omega 6 / \omega 3$ : ratio of $\omega 6$ to $\omega 3$ fatty acids. 
Therefore, in dietary terms, it can be affirmed that the meat of the Limousin and Nelore breeds and also the Simmental and Nelore breed fed with the CY and $\mathrm{CHY}$ diet showed less cholesterol contents, higher $\mathrm{P} / \mathrm{S}$ ratio and smaller $\omega 6 / \omega 3$ ratio in relation to all the diets. However, as in Brazil the cassava has low price compared to the price of the corn, the use of $\mathrm{CHY}$ diet represents a good economy factor.

\section{Conclusions}

1. Feeding CHMB diets provides lower lipid and higher cholesterol contents for both crosses.

2. Most of the identified acids are monounsatured and among them, oleic acid has the highest percentage, with values between 32.54 and $46.24 \%$.

3. Among the saturated fatty acids, palmitic acid has the highest percentage, with values between 19.40 and $32.44 \%$.

4. The highest and lowest acid ratio (polyunsaturated/saturated) are 0.30 and 0.08 .

5. Feeding CY diets provides lower cholesterol and higher polyunsaturated fatty acid contents of the Longissimus muscle.

\section{Acknowledgements}

To CNPq and CAPES for financial support.

\section{References}

ABULARACH, M. L. S.; ROCHA, C. E.; FELÍCIO, P. E. Características de qualidade do contrafilé (m. L. dorsi) de touros jovens da raça Nelore. Ciência e Tecnologia de Alimentos, Campinas, v. 18, p. 205-210, 1998.

AHARONI, Y.; NACHTOMI, E.; HOLSTEIN, P.; BROSH, A.; HOLZER, Z.; NITSAN, Z. Dietary effects on fat deposition and fatty acid profiles in muscle and fat depots of Friesan bull calves. Journal of Animal Science, Savoy, v. 73, p. 2712-2720, 1995.

AL-HASANI, S. M.; HLAVAC, J.; CARPENTER, M. W. Rapid determination of cholesterol in single and multicomponent prepared foods. Journal of the Association Official Analytical Chemists International, Gaithersburg, v. 76, n. 4, p. 902-906, 1993.

BOHAC, C. E.; RHEE, K. S. Influence of animal diet and muscle location on cholesterol content of beef and pork muscles. Meat Science, Oxford, v. 23, p. 71-75, 1988.
CUNNIFF, P. A. (Ed.). Official methods of analysis of the Association of Official Analytical Chemists. 16. ed. Arlington: Association of Official Analytical Chemists, 1998. $2 \mathrm{v}$.

EICHORN, J. M.; COLEMAN, L. J.; WAKAYAMA, E. J.; BLOMQUIST, G. J.; BAILEY, C. M.; JENKINS, T. G. Effects of breed type and restricted versus ad libitum feeding on fatty acid composition and cholesterol content of muscle and adipose tissue from mature bovine females. Journal of Animal Science, Savoy, v. 63, p. 781-785, 1986.

ENGLAND. Department of Health. Nutritional aspects of cardiovascular disease. London: HMSO, 1994. p. $37-$ 46. (Report on Health and Social Subjects, 46).

ENSER, M.; HALLET, K. G.; HEWETT, B.; FURSEY, G. J.; WOOD, J. D. Fatty and composition of English beef, lamb and pork at retail. Meat Science, Oxford, v. 42, p. 443-456, 1996.

FEELEY, R. M.; CRINER, P. E.; WATT, B. K. Cholesterol content of foods. Journal of the American Dietetic Association, Chicago, v. 61, p. 134, 1972.

FOLCH, J.; LEES, M.; STANLEY, G. H. S. A simple method for the isolation and purification of total lipids from animal tissues. Journal of Biological Chemistry, Bethesda, v. 226, p. 497-509, 1957.

HOLLAND, B.; WELCH, A. A.; UNWIN, I. D.; BUSS, D. H.; PAUL, A. A.; SOUTHGATE, D. A. T. McCance and Widdowson's: the composition of foods. 5. extended ed. Suffolk: Richard Clay, 1993. 215 p.

INTERNATIONAL ORGANIZATION FOR STANDARDIZATION (Geneve, Switzerland). Animal and vegetable fats and oils: preparation of methyl esters of fatty acids: (Method ISO 5509). Geneve, 1978. p. 1-6.

KATAN, M. B.; ZOCK, P. L.; MENSINK, R. P. Effects of fats and fatty acid on blood lipids in humans: an overview. American Journal of Clinical Nutrition, Bethesda, v. 60, p. 1017S-1022S, 1994. Supplement.

KOEVERING, M. T. van; GILL, D. R.; OWENS, F. N.; DOLEZAL, H. G.; STRASIA, C. A. Effect of time on feed on performance of feedlot steers, carcass characteristics, and tenderness and composition of longissimus muscles. Journal of Animal Science, Savoy, v. 73, p. 21-28, 1995.

MILLS, E. W.; COMERFORD, J. W.; HOLLENDER, R.; HARPSTER, H. W.; HOUSE, B.; HENNING, W. R. Meat composition and palatability of Holstein and beef steers as influenced by forage type and protein source. Journal of Animal Science, Savoy, v. 70, p. 2446-2451, 1992. 
MONTGOMERY, D. C. Design and analysis of experiments. 4. ed. New York: J. Wiley, 1997. 704 p.

O'DEA, K.; TRAIANEDES, K.; CLISHOLM, K.; LEYDEN, H.; SINCLAIR, A. J. Cholesterol: lowering effect of a low fat diet containing lean beef is reversed by the addition of beef fat. American Journal of Clinical Nutrition, Bethesda, v. 52, p. 491, 1990.

PALEARI, M. A.; CAMISASCA, S.; BERETTA, G.; RENON, P.; CORSICO, P.; BERTOLO, G.; CRIVELLI, G. Ostrich meat: physical-chemical characteristics and comparison with turkey and bovine meat. Meat Science, Oxford, v. 48, p. 205-210, 1998.
ROWE, A.; MACEDO, F. A. F.; VISENTAINER, J. V.; SOUZA, N. E.; MATSUSHITA, M. Muscle composition and fatty acid profile in lambs fattened in drylot or pasture. Meat Science, Oxford, v. 51, p. 283-288, 1999.

RULE, D. C.; MacNEIL, M. D.; SHORT, R. E. Influenced of sire growth potential, time on feed, and growing-finishing strategy on cholesterol and fatty acids of the ground carcass and longissimus muscle of beef steers. Journal of Animal Science, Savoy, v. 75, p. 1525-1533, 1997.

STATISTICA. Statistica 5.1 software. Tucksa: StatSoft, 1996. 